\title{
大豆油の高壓水素添加に關する研究（第6 報）
}

不飽和嗃㿮アルコホルの生成に就て

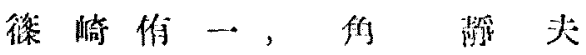

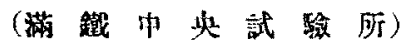

昭和 13 年 7 月 4 日受理

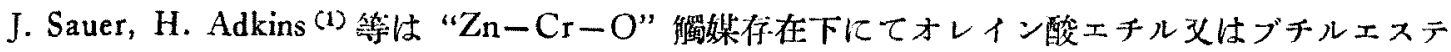
ル及びェルカ酸ブチルェステル等につき高然還元を行ひ，夫ょオレインアルコホル，エルシルアル コホルを $60 \%$ 以上の高收量にて得をりと報告せり。

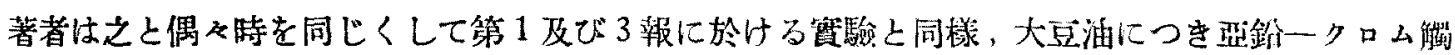

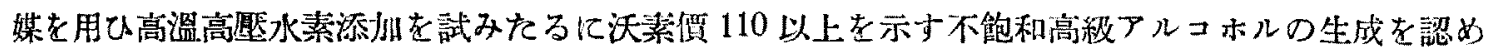

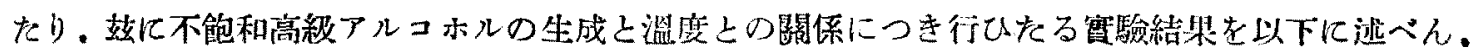

\section{1. 蒀 驗方 法}

\section{實 验 之 部}

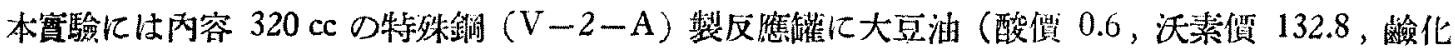

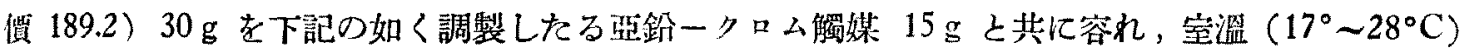

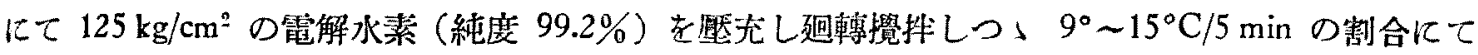
温度を上昇せしめ所定溫度に䞗すれば道ちに加熱源を去りて放冷したり。

解媒の調製: 一 重クロム酸安母ट硝酸亞鉛との複分解に上り作りたるクロム酸安母亞鉛を $335^{\circ}$ $350^{\circ} \mathrm{C}$ にて 2 時間炶成の後，250目/时通過の粉末ししたるものにして帶綠黑色を是し Cr 32.8

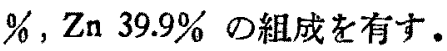

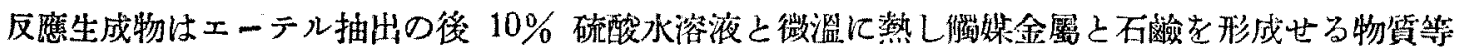
の分解を行ひ，上く水洗乾燥の後分析に供したり。

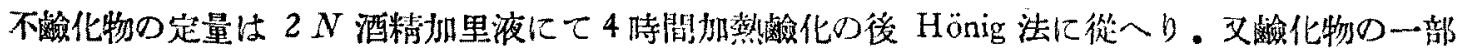
を監酸にて再び分解遊離せしめ此物につき分析を行ひ之より

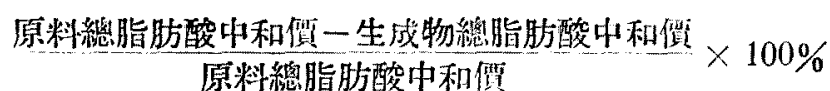

を求め之をカルボキシル基轉掺率と䊈せり．之は脂肪酸メは脂肪酸エステル中のカルボキシル基の 高歷還元反應による他の分子團（アルコホル，アルデヒト，炭化水絜器）八の變化の程度孝示す。

X

$$
\frac{\text { 生成物了七チル偨 }}{180.2} \times 100 \%
$$

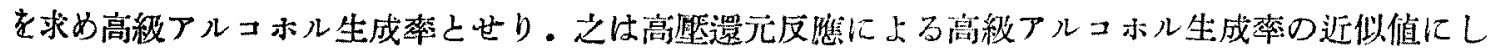
て生成高級アルコホルを全部オンインアルコホルと見做して計估せるものなり。

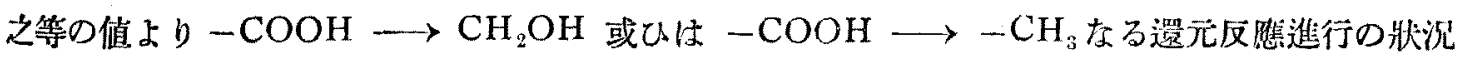
を考察し，一方之と同時に各生成物につき沃素価（ハメス法による）の變化を檢し二重綃合に對 する還元反雔の狀況を檢したり． 
2. 反碓溫度之生成物

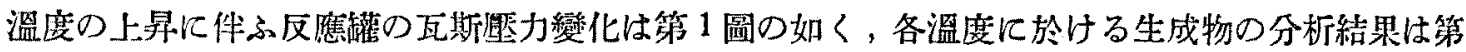
1 表及び第2 圖に示すが如し.

第 1 圖

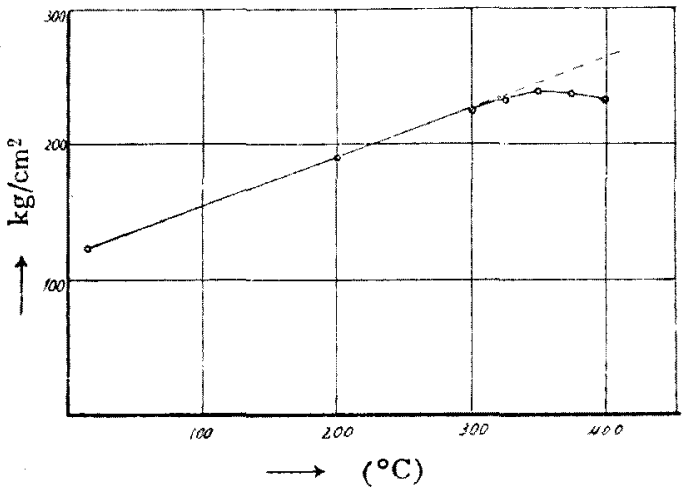

第 2 圖

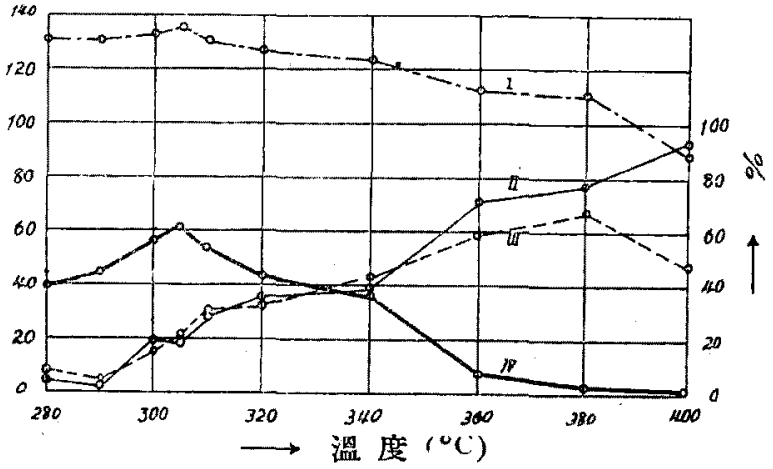

I 沃度借 II カルボキシル基轅換率

III アルコホル生成萃 IV 酸湖 第 1 表

\begin{tabular}{|c|c|c|c|c|c|c|}
\hline 反 盟 & 位 ${ }^{\circ} \mathrm{C}$ & 280 & 290 & 300 & 305 & 310 \\
\hline 牧 & 量 & 87.9 & 87.0 & 87.2 & 86.8 & 84.2 \\
\hline 酸 & 僧 & 39.2 & 44.8 & 56.7 & 62.2 & 54.1 \\
\hline 龄 & 僄 & 181.3 & 189.3 & 154.2 & 149.9 & 135.6 \\
\hline$P \quad t$ & ル 偲 & 6.2 & 6.3 & 21.4 & 34.3 & 49.9 \\
\hline \multirow{3}{*}{ 醶化䢍踓物 } & 中 和 䨘 & 188.9 & 193.2 & 159.3 & 159.1 & 142.1 \\
\hline & アセチル儒 & 14.1 & 7.7 & 12.1 & 37.2 & 55.9 \\
\hline & 沃 素 價 & 130.9 & 130.7 & 132.9 & 135.3 & 130.1 \\
\hline \multirow{2}{*}{\multicolumn{2}{|c|}{$\begin{array}{l}\text { カルボキシル基䡒換葬 } \\
\text { アルコホル生成率 }\end{array}$}} & 4.9 & 2.8 & 19.8 & 19.9 & 28.5 \\
\hline & & 7.8 & 4.2 & 16.1 & 20.6 & 31.0 \\
\hline
\end{tabular}

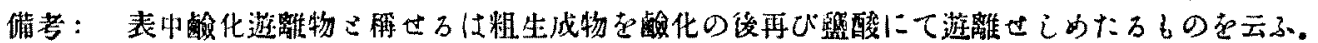
以下の表に於ても之に準す。

第就

\begin{tabular}{|c|c|c|c|c|c|c|}
\hline 反 哭 & 温 㡲 ${ }^{\circ} \mathrm{C}$ & 320 & 340 & 360 & 380 & 400 \\
\hline 收 & 量 & 83.2 & 84.2 & 80.1 & 84.1 & 81.9 \\
\hline 酸 & 佂 & 42.9 & 38.1 & 6.3 & 3.4 & 1.6 \\
\hline 敞期 & 增 & 124.6 & 103.3 & 55.8 & 42.3 & 9.1 \\
\hline$>\quad t$ & チル眥 & 49.1 & - & - & - & - \\
\hline \multirow{3}{*}{ 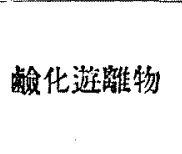 } & 中 和 䍀 & 127.2 & 122.3 & 56.4 & 43.6 & 12.3 \\
\hline & アセチル俔 & 61.3 & 79.1 & 106.5 & 121.5 & 86.1 \\
\hline & 沃 素 佂 & 127.2 & 123.8 & 112.3 & 111.3 & 88.2 \\
\hline \multirow{2}{*}{\multicolumn{2}{|c|}{ 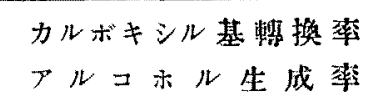 }} & 36.0 & 38.4 & 71.6 & 78.0 & 93.8 \\
\hline & & 33.8 & 43.8 & 59.1 & 67.5 & 47.5 \\
\hline
\end{tabular}


上表に據れば $290^{\circ} \mathrm{C}$ 附近までにはカルボキシル基り轉撸極めて少なく從つて高級アルコホルの

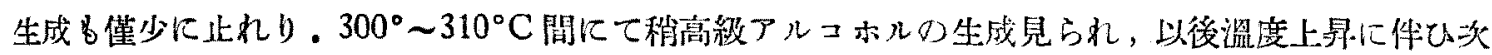

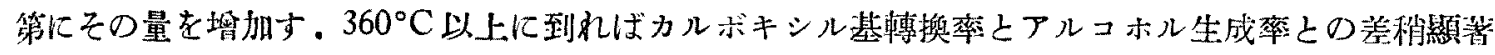
となり $400^{\circ} \mathrm{C}$ に及びアルコホル生成率却つて減少を示したり。而して沃素得は $320^{\circ} \mathrm{C}$ 附近まで 殆んど變化なく以後，溫度上景に件ひ漸次減少の傾向が認めらるるも，その程度比較的僅少にして $400^{\circ} \mathrm{C}$ に於て少 88.2 を示したり。

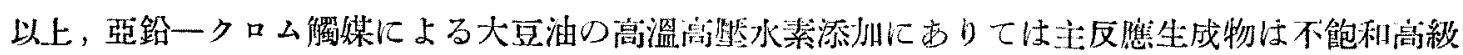
アルコホルにして $300^{\circ} \sim 380^{\circ} \mathrm{C}$ 間にてその生成反應が認められ，360兄を超りるとをは同時に桨 化水素への還元を件ふてと著し。

\section{3. 反應生成物の確認}

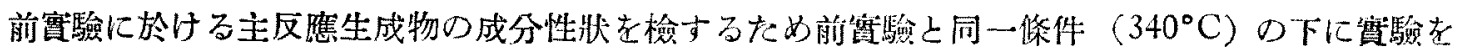
繰返して得たる粗生成物につき次の如き檢热を行ひたり。的ち粗生成物 $56 \mathrm{~g}$ 在 15 倍量の $2 N$ 酒 精加里液と共に 5 時間撂化し Hönig 法によりて不醶化物を分踓し, 閤化水溶液部は合して濃縮の 後墭酸にて遊離せしめ油狀部をェーテルにて抽出, 水洗, 乾燥するに褐色透明の液體 $26 \mathrm{~g}$ (粗生成 物の 46.4\%に相當す) を得たり。その性狀は

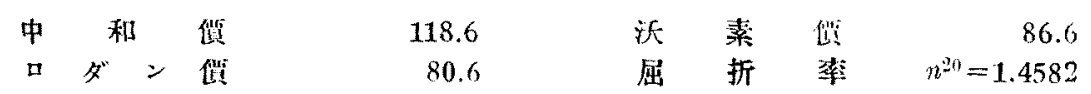

にして更に椸色精製の後分析するに

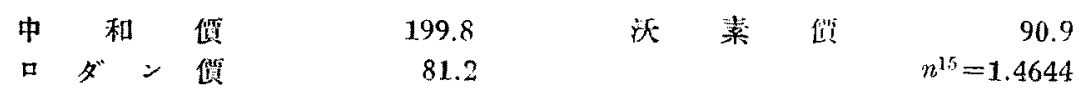

を示し，正オレイン酸とよく一致せり。

次に不制化物（エーテル可溶部）は之を溫水にて上く水洗の後, 乾煤するに $3 \mathrm{~g}$ (粗生成物の 40.1

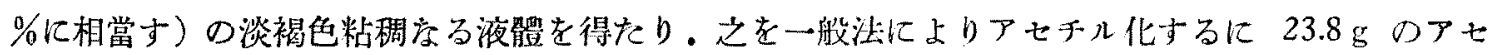

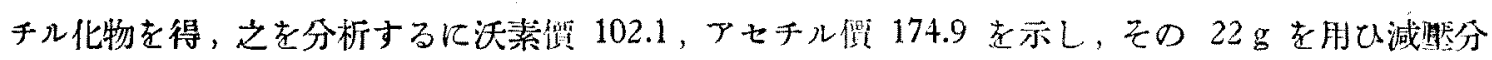
溜に附すに $12 \mathrm{~mm}$ にて $180^{\circ} \mathrm{C}$ 附近上り溜出始まり以下の如き溜分を得たり。

\begin{tabular}{|c|c|c|c|c|c|c|c|}
\hline 溜 分 & $\begin{array}{l}\text { 減㩔度 } \\
(\mathrm{mm})\end{array}$ & 度 & 收 量 & 溜 分 & 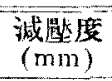 & 底 & 收 量 \\
\hline (1) & 12 & $180^{\circ} \sim 198^{\circ} \mathrm{C}$ & $1.4 \mathrm{~g}$ & (4) & 12 & $210^{\circ} \sim 217^{\circ} \mathrm{C}$ & $3.0 \mathrm{~g}$ \\
\hline (2) & $13 \sim 14$ & $203^{\circ} \sim 204^{\circ} \mathrm{C}$ & $7.1^{\prime \prime}$ & (5) & 殘 洹 & & \\
\hline (3) & 13 & $206^{\circ} \mathrm{C}$ & $9.0^{\prime \prime}$ & & & & \\
\hline
\end{tabular}

各溜分につき分析するに次の如く，

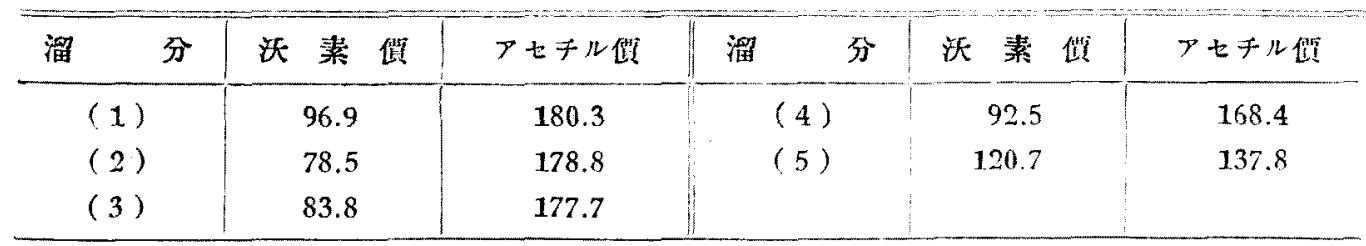

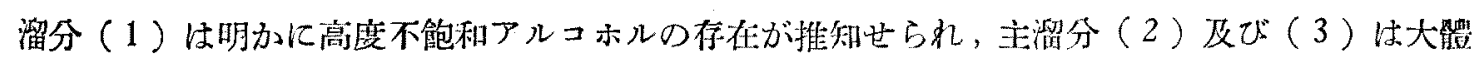

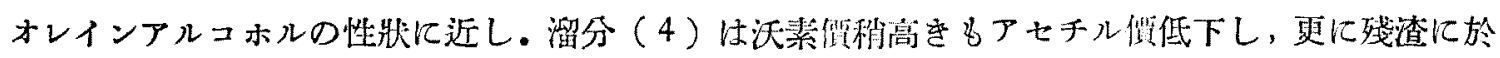
ては著しき低下を示し明らかに不純分（炭化水素）の混在が推察さる。溜分（2）及ざ(3) 䓃 
して常法に從ひ簽化し高級アルコホル分を抽出，精製するに淡褐色の透朋液體となり，屈折率 $n^{20}$ $=1.4601$ を示したり.此物筫につをエチルアルコホルを溶媒としパラジウム能媒により水素涯加を

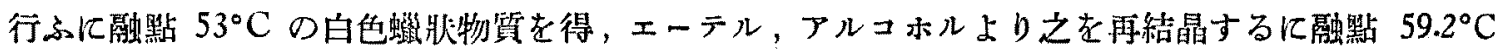
を示しよくオクタデカノール（融點 $59^{\circ} \mathrm{C}$ ) と一致したり，從つて該溜分はォクタデセノールを主

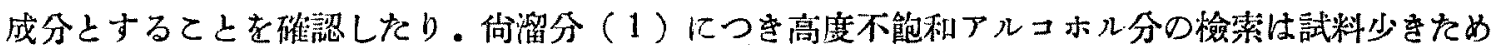
遂行し得ざりき.

\section{要 約}

（1）亞鈆ク口ム蠋媒の存在下にて大豆油の高㷦水素添加老行ひ，溫度上昇に件ふ生成物の變化を。 檢したり。

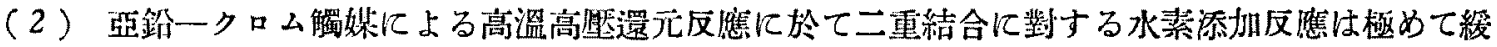
慢にして $400^{\circ} \mathrm{C}$ に到るも何, 沃素賈 88.2 を示したるる高級アルコホルの還元反應は $300^{\circ} \mathrm{C}$ 附近上り明らか儿認められ $380^{\circ} \mathrm{C}$ に到る迄溫度上昇之共に次第に旺盛となれり。

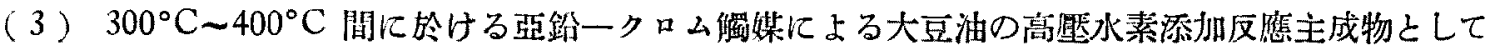
オレインアルコホルを䅹認したり。

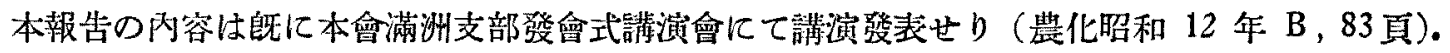
本研究の第 1 報乃至第 5 報々工業化學稚誌（昭和 9 年 1478 頁，1481 頁，1674 頁，昭和 10 年56 貢，昭和 11 年 40 頁) 上汇記載發表せり。

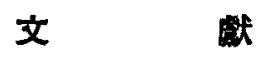

(1) J. Sauer, I. Adkins: J. Ame. Chem, Soc., 59, 1 (1937) 